\title{
Superoxide and Hydrogen Peroxide Play Different Roles in the Nonhost Interaction of Barley and Wheat with Inappropriate formae speciales of Blumeria graminis
}

\author{
Marco Trujillo, Karl-Heinz Kogel, and Ralph Hückelhoven \\ Interdisciplinary Research Centre for Environmental Sciences, Institute of Phytopathology and Applied Zoology, \\ Justus-Liebig-University Giessen, Heinrich-Buff Ring 26-32, D-35392 Giessen, Germany
}

Submitted 5 September 2003. Accepted 17 November 2003.

\begin{abstract}
Nonhost resistance of cereals to inappropriate formae speciales of Blumeria graminis is little understood. However, on the microscopic level, nonhost defense to $B$. graminis is reminiscent of host defense preventing fungal development by penetration resistance and the hypersensitive cell death response (HR). We analyzed histochemically the accumulation of superoxide anion radicals $\left(\mathrm{O}_{2}{ }^{-}\right)$and hydrogen peroxide $\left(\mathrm{H}_{2} \mathrm{O}_{2}\right)$ at sites of $B$. graminis attack in nonhost barley and wheat. Superoxide visualized by subcellular reduction of nitroblue tetrazolium accumulated in association with successful fungal penetration in attacked cells and in cells neighboring $\mathrm{HR}$. In contrast, $\mathrm{H}_{2} \mathrm{O}_{2}$ accumulated in cell wall appositions beneath fungal penetration attempts or in the entire epidermal cell during HR. The data provide evidence for different roles and sources of superoxide and $\mathrm{H}_{2} \mathrm{O}_{2}$ in the nonhost interaction of cereals with inappropriate formae speciales of B. graminis.
\end{abstract}

Plant nonhost resistance is expressed effectively by plants against the majority of microorganisms that are potential pathogens. Nonhost resistance is complete and durable, and understanding the underlying signal transduction and defense mechanisms might help to improve crop resistance. Nonhost resistance is genetically complex and the contribution of preformed barriers and activated defense may be different in each particular nonhost-pathogen interaction. The role of nonspecific elicitor receptors or specific resistance protein-like factors in the perception of inappropriate pathogens is hardly understood (Heath 2000; Kamoun 2001; Tosa and Sakai 1990). Thus, the multiplicity of defense factors involved in nonhost resistance may segregate individually between species without affecting its efficiency (Heath 2000; Thordal-Christensen 2003).

In contrast to race-cultivar-specific resistance, nonhost resistance is species or formae speciales specific. For instance, grasses can be infected only by one appropriate forma specialis of grass powdery mildew fungus, Blumeria graminis. During attempted infection of nonhost barley by inappropriate $B$. graminis f. sp. tritici (wheat powdery mildew fungus) and wheat by inappropriate B. graminis f. sp. hordei (barley pow-

Corresponding author: R. Hückelhoven; Fax: +49-641-9937499; E-mail: Ralph.Hueckelhoven@agrar.uni-giessen.de

This article is in the public domain and not copyrightable. It may be freely reprinted with customary crediting of the source. The American Phytopathological Society, 2004. dery mildew fungus), a certain level of accessibility is observed in the sense that the fungus is able to penetrate some cells, producing a haustorium. However, this organ often degenerates in the later time course of infection (Heath 1987; Tosa and Shishiyama 1984). In barley, the degree of $B$. graminis f. sp. tritici development and resistance response is dependent on both the fungal isolate and the plant genotype (Tosa and Shishiyama 1984), reminiscent of cultivar-specific resistance. Genetic evidence coming from crosses of grass powdery mildews shows that forma specialis nonhost resistance most probably acts on the basis of several gene-for-gene relationships (Flor 1971; Matsumara and Tosa 1995; Tosa and Tada 1990).

This also suggests that barley can be a suitable substrate for B. graminis f. sp. tritici and that active plant defense is crucial in this interaction. The suitability of nonhost barley as a substrate is supported by the observation that preinoculation of barley with $B$. graminis f. sp. hordei can suppress nonhost resistance, allowing a secondary challenger, such as the inappropriate formae speciales $B$. graminis $\mathrm{f}$. sp. tritici, to sporulate (Olesen et al. 2003). The combination of gene-specific resistance and substrate suitability in some nonhost interactions recently was demonstrated in Arabidopsis mutants. In particular, the eds1 Arabidopsis mutant that is impaired in resistance gene signaling supported growth and sporulation of $B$. graminis f. sp. tritici when actin function additionally was inhibited (Falk et al. 1999; Yun et al. 2003).

Taken together, fungal infection attempts and plant defense responses observed in interactions of $B$. graminis with grass nonhosts are similar to those seen in appropriate but incompatible interactions and, accordingly, defense reactions such as cell wall appositions (papillae), hypersensitive reaction (HR), and accumulation of phenolic substances in the attacked cell are present in host as well as nonhost interactions (Carver et al. 1992; Tosa and Shishiyama 1984).

Since Doke (1983) discovered superoxide generation preceding the HR in potato cells during penetration by an avirulent isolate of Phytophthora infestans, superoxide has been considered as a key component of plant defense. Superoxide and other reactive oxygen intermediates (ROI) such as hydrogen peroxide ( $\mathrm{H} 2 \mathrm{O} 2)$ have been postulated to play central and manifold roles in plant host as well as nonhost resistance to fungal pathogens, including powdery mildew fungi (Hückelhoven et al. 2001a; Mellersh et al. 2002; ThordalChristensen et al. 1997). Among the effects of ROI are induction of cell death (Delledonne et al. 2001; Levine et al. 1994), membrane deterioration (Ádám et al. 1989; Benov 2001), protein cross-linking (Bradley et al. 1992; Brisson et al. 
1994), elicitor signal transduction (Jabs et al. 1996), and systemic acquired resistance (Alvarez et al. 1998; Hückelhoven and Kogel 2003; Lamb and Dixon 1997). It is well accepted that ROI are implicated in plant cell death, although it is not well established to what extent individual ROI induce cell death or play a role in lesion restriction (Hückelhoven and Kogel 2003; Levine et al. 1994). The latter apparently works via activation of antioxidative cell protectants such as glutathione-S-transferase that is expressed in response to $\mathrm{H}_{2} \mathrm{O}_{2}$ and nonhost grass powdery mildew in soybean cells, wheat, and Arabidopsis (Levine et al. 1994; Mauch and Dudler 1993; Yun et al. 2003). According to that, ROI production in the interaction of barley with $B$. graminis f. sp. hordei is accompanied by activation of a set of antioxidants (Vanacker et al. 2000). It has been reported that $\mathrm{O}_{2}{ }^{-}$is necessary and sufficient to trigger cell death. However, $\mathrm{O}_{2}{ }^{-}$also induced leaf lesions in the Arabidopsis mutant $l s d l$ but not in the wild type, further indicating a dual role for $\mathrm{O}_{2}{ }^{--}$in cell death regulation (Jabs et al. 1996). $\mathrm{O}_{2}{ }^{--}$produced in the apoplast, possibly by NADPH oxidase activity, is not membrane permeable but is rapidly converted either spontaneously or enzymatically via superoxide dismutase to $\mathrm{H}_{2} \mathrm{O}_{2}$ that can cross membranes (Hammond-Kosack and Jones 1996). ROI interaction with other signal molecules such as NO complements ROI function and regulates $\mathrm{HR}$ in a ROI-specific manner (Delledonne et al. 2001).
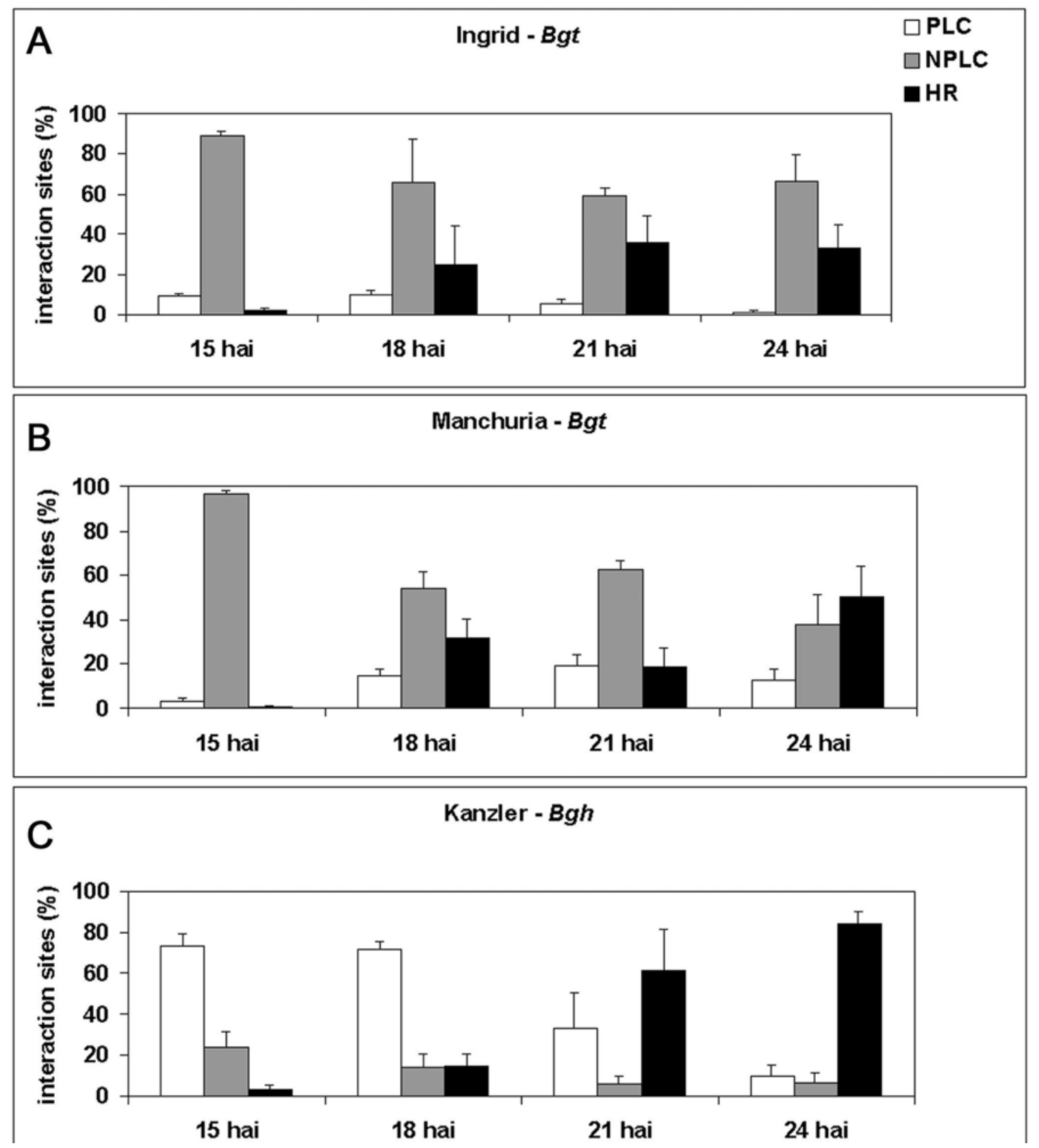

Fig. 1. Quantitative cytological analysis of defence responses of the nonhost barley cvs. A, Ingrid and B, Manchuria upon infection with Blumeria graminis f. sp. tritici (Bgt) isolate A95, and C, the nonhost wheat cv. Kanzler with B. graminis f. sp. hordei (Bgh)isolate A6. Primary leaves were inoculated and analyzed at 15, 18, 21, and 24 hours after inoculation (hai). White columns: Frequency of penetrated living cells (PLC) containing nondifferentiated haustoria. Grey columns: Nonpenetrated living cells (NPLC) in which fungal penetration was prevented by formation of cell wall appositions (papillae). Black columns: Hypersensitive response (HR) of a single attacked nonhost cell. Each column represents an average value of four repetitions of each at least 100 single-cell interaction sites per leaf. Error bars represent the standard deviation of four repetitions. Repetition of the experiment led to results very similar to those shown. 
Prior investigations have shown that $\mathrm{O}_{2}{ }^{-}$is not a single key determinant of HR in the interaction of barley with appropriate powdery mildew fungus (Hückelhoven and Kogel 1998). Rather, $\mathrm{O}_{2}{ }^{-}$was observed in association with successful penetration and in mesophyll cells subtending HR. The accumulation of $\mathrm{H}_{2} \mathrm{O}_{2}$, on the other hand, is related mainly to two types of defense reactions. First is the formation of highly localized cell wall appositions, which are formed in response to the attachment of the primary and secondary germ tubes conferring race-nonspecific penetration resistance. This type of resistance is expected to prevent direct contact of fungal infection structures with the host plasma membrane. Second, $\mathrm{H}_{2} \mathrm{O}_{2}$ accumulation takes place throughout the entire epidermal host cell during the HR, which is triggered race specifically in host resistance (Hückelhoven and Kogel 2003; Thordal-Christensen et al. 1997).

The unique characteristics of the barley and wheat interaction with the inappropriate formae speciales of the biotrophic fungi $B$. graminis represent a suitable tool to elucidate the role of ROI in the defense reaction. We report here that $\mathrm{O}_{2}{ }^{-}$is generated with high frequency in penetrated cells and cells neighboring $\mathrm{HR}$, as indicated by in situ $\mathrm{O}_{2}{ }^{--}$detection with ni-
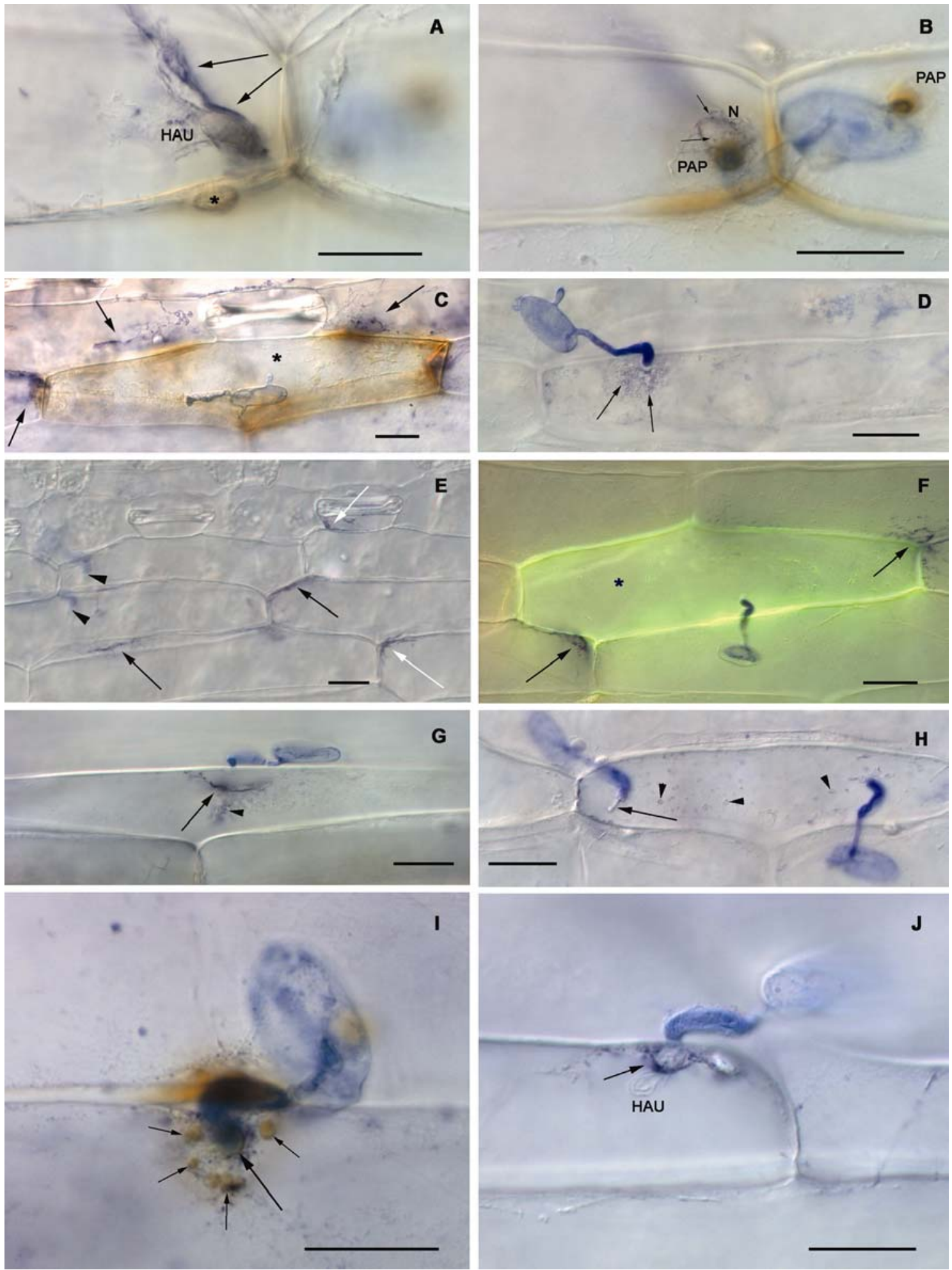
troblue tetrazolium (NBT). Additionally, we performed an NBT-3,3-diaminobenzidine (DAB) double staining to investigate simultaneous accumulation of $\mathrm{O}_{2}{ }^{--}$and $\mathrm{H}_{2} \mathrm{O}_{2}$. We show that $\mathrm{O}_{2}{ }^{-}$and $\mathrm{H}_{2} \mathrm{O}_{2}$ accumulation patterns differ from each other and depend on the type of defense reaction.

\section{RESULTS}

\section{Interaction phenotypes of barley and wheat} with inappropriate formae speciales of $\boldsymbol{B}$. graminis.

We analyzed microscopically the nonhost interaction phenotypes of the barley cvs. Ingrid and Manchuria with $B$. graminis f. sp. tritici (wheat powdery mildew fungus), isolate A95, and the wheat cv. Kanzler with B. graminis f. sp. hordei (barley powdery mildew fungus), isolate A6, at 15, 18, 21, and $24 \mathrm{~h}$ after inoculation (hai). Cytoplasmic activity was detected already at 15 hai beneath appressoria and decreased during the time course of the interactions. Effective penetration resistance of living cells (nonpenetrated living cells [NPLC]) was highest in Ingrid with $67 \%$ at 24 hai. In contrast, the penetration and HR rate $(33 \%)$ in Ingrid was the lowest of all three nonhost interaction combinations, demonstrating the most effective prehaustorial defense (Fig. 1).

In contrast to Ingrid, Manchuria was penetrated with a maximal frequency of $19 \%$ at 21 hai and, accordingly, it presented more HR than Ingrid. Manchuria's HR rate increased to a maximum of $50 \%$ at 24 hai. Additionally, haustoria were detectable in $34 \%$ of HR cells in Ingrid and 32\% in Manchuria, indicating a link between penetration and onset of HR (data not shown). Penetration defense in Manchuria was poor and NPLC accounted for $37 \%$ of interactions at 24 hai.

B. graminis f. sp. hordei effectively penetrated the wheat cv. Kanzler as early as 15 hai with a frequency of $73 \%$ (Fig. 1). During the time course of the experiment, living cells containing haustoria were replaced by HR cells ( $84 \%$ at 24 hai). Furthermore, $70 \%$ of HR cells exhibited an immature and mostly degenerated haustorium (not shown). Formation of visible papillae in NPLC almost was absent during the time course of interaction.

\section{Cellular localization of $\mathrm{O}_{2}{ }^{--}$.}

Cytological detection of $\mathrm{O}_{2}^{--}$was achieved by NBT application. NBT then was stepwise reduced to dark-blue formazans by superoxide radicals. We analyzed simultaneously NBT staining patterns and the interaction phenotypes mentioned above. To impede the direct reduction of NBT in mitochondria, azide was added to the staining solution to ensure the detection of $\mathrm{O}_{2}{ }^{-}$. However, the reduction of NBT by other molecules cannot be ruled out entirely in planta. In absence of azide, NBT reduction possibly indicates increased dehydrogenase activity in mitochondria (Heath 1998; unpublished observations).

The majority of interaction sites, where the fungus was able to penetrate and establish an immature haustorium, displayed NBT staining close to the plasma membrane near the penetration attempt or, less frequently, around the haustorium (Fig. 2A, D, G, and J). NBT staining in penetrated living cells (PLC) was most intensive in wheat. In addition to strong localized staining, weak NBT staining sometimes also could be detected throughout the whole cell periphery in Ingrid (Fig. 2H).

Vesicle-like bodies of maximally 1 to $2 \mu \mathrm{m}$ showed darkblue NBT staining (Fig. 2D). These were located at the plasma membrane, in the cytoplasm, and at the nucleus.

HR-related cell death led to whole-cell autofluorescence and loss of cell integrity as judged by the absence of cytoplasmic strands and granulation of the cytoplasm (Fig. 2F). Most obviously, cells that had undergone an HR never accumulated superoxide. Instead, neighboring epidermal or mesophyll cells showed NBT staining close to the cell wall facing the HR (Fig. $2 \mathrm{C}$ and $\mathrm{F}$ ). The number of cells displaying NBT staining adjacent to HR varied and seemed to be dependent on the intensity of the defense reaction. In Ingrid, localized NBT staining was observed in epidermal cells separated from the attacked cell by one to two epidermal cells at the plasma membrane facing the single cell HR (Fig. 2E). Most NPLCs did not show any NBT staining.

\section{Simultaneous detection of $\mathrm{O}_{2}{ }^{--}$and $\mathrm{H}_{2} \mathrm{O}_{2}$.}

$\mathrm{O}_{2}{ }^{--}$and $\mathrm{H}_{2} \mathrm{O}_{2}$ generation were analyzed simultaneously at 18 hai. We considered this time point to be most suitable for analysis because prior studies indicated it to be pivotal in the infection process and adequate for detection of $\mathrm{O}_{2}{ }^{--}$production (Hückelhoven and Kogel 1998). In contrast to NBT-derived formazan, which is dark blue and granulated, DAB polymers indicative for $\mathrm{H}_{2} \mathrm{O}_{2}$ are brownish and diffuse. Parallel detection of $\mathrm{DAB}$ and formazan indicated spatiotemporal-specific production for distinct ROI.

Most conspicuously, DAB staining always was present within HR cells and, in most cases, accompanied by NBT staining in neighboring epidermis or mesophyll cells (Fig. 2C).

Cell wall appositions not penetrated by $B$. graminis were stained intensely with DAB, while NBT staining rarely was detected in NPLC (more DAB-staining pictures can be found in Hückelhoven et al. 2001a). NBT staining was located

Fig. 2. Micrographs of histochemical detection of reactive oxygen intermediates (ROI) during the nonhost interactions of barley and wheat with the inappropriate formae speciales of Blumeria graminis. Primary leaves were treated with ROI-indicating compounds nitroblue tetrazolium (NBT) and 3,3diaminobenzidine (DAB) and analyzed for detection of formazans representative for $\mathrm{O}_{2}$ production or DAB polymerization indicating $\mathrm{H}_{2} \mathrm{O}_{2}$ accumulation. A through $\mathbf{C}$ and I, Interactions where NBT and DAB double staining was performed. D through $\mathbf{H}$ and $\mathbf{J}$, Interactions stained only with NBT. A, Epidermal cell of the barley cv. Ingrid penetrated by B. graminis f. sp. tritici at 18 hours after inoculation (hai). Cell displays at the lower focal plane, plasma membrane located NBT staining (arrows) near and adjacent to the haustorium initial (HAU). Also visible is the displacement of the cell nucleus of the neighbor cell (asterisk) to the cell wall. B, Same interaction at an upper focal plane, where DAB polymerization in the papillae (PAP) becomes visible under primary and secondary germ tubes and at the cell wall. The cell nucleus (N) is closely associated to the penetration site and displays NBT staining (small arrows). C, Interaction of the wheat cv. Kanzler with B. graminis f. sp. hordei. The penetrated epidermal cell underwent HR and displays whole-cell DAB staining (asterisk) and NBT staining in the neighboring epidermal cells at the cell membrane adjacent to the attacked cell (arrows). D, NBT staining in an Ingrid epidermal cell around the penetration area 18 hai with $B$. graminis f. sp. tritici. NBT-stained vesicle-like bodies (arrows) are visible in the vicinity of the penetration site. E, Penetration of Ingrid epidermal cells at 18 hai by B. graminis f. sp. tritici (arrowheads) induced localized NBT staining in neighbor cells at the adjacent cell membrane (arrows) and in cells separated from the attacked cell by one epidermal cell at the cell membrane facing the attacked cell (white arrows). F, Manchuria epidermal cell that underwent HR (asterisk) at 18 hai. HR cell displays autofluorescence and neighboring cells show NBT staining at the adjacent cell membrane (arrows). G, Kanzler epidermal cell penetrated by B. graminis f. sp. hordei at 15 hai, with NBT staining at the cell membrane subtending the penetration point (arrow). NBT staining also detectable in the cytoplasm (arrowhead). H, Ingrid-B. graminis f. sp. tritici interaction at 15 hai, haustoria initials (arrow) and granular NBT staining are visible in the whole cell and in vesicle-like bodies (arrowheads). I, Ingrid- $B$. graminis f. sp. tritici interaction 18 hai, in which a DAB-stained papilla (arrow) was formed subjacent to the secondary germ tube accompanied by DABstained vesicle-like bodies (small arrows) and NBT granules. J, Penetrated Kanzler epidermal cell, in which B. graminis f. sp. hordei established a haustorium initial (HAU) and localized NBT staining is visible (arrow). Scale bar $=20 \mu \mathrm{m}$. 
around the papillae but never within the subcellular DABstained part (Fig. 2I). DAB-stained vesicle-like bodies reached a size of up to $4 \mu \mathrm{m}$ and were observed in the vicinity of papilla, apparently transporting material for apoplastic defense (Fig. 2I) (Collins et al. 2003). Vesicle-like bodies never displayed both types of ROI staining. At a few sites, NBT staining at the plasma membrane accompanied successful penetration and simultaneously DAB stained the papilla and anticlinal cell wall (Fig. 2A, B).

\section{Frequencies of $\mathrm{O}_{2}^{--}$production.}

NBT staining was quantified by counting interaction sites at 18 and 24 hai. Ingrid showed high-penetration resistance (67\%, 24 hai) and only 11\% of NPLC displayed detectable NBT staining at 18 hai (Fig. 3). In the same interaction, only $33 \%$ of attacked cells showed HR. However, $66 \%$ of the cells neighboring HR cells showed NBT staining at 24 hai. About $11 \%$ of the fungi developed a haustorium initial at 18 hai; $40 \%$ of the PLCs exhibited a reaction with detectable NBT staining within the attacked cell (Fig. 3).

The barley cv. Manchuria displayed a relatively high accessibility to $B$. graminis f. sp. tritici, allowing the formation of a haustorium initial in up to $14 \%$ of all interactions at 18 hai and survival of most penetrated cells until 24 hai. However, only $21 \%$ of the PLCs showed NBT staining (Fig. 3). The overall proportion of cells that showed $\mathrm{O}_{2}{ }^{--}$staining was lower than in barley cv. Ingrid and the wheat cv. Kanzler. Consistently, an intermediate penetration rate between barley cv. Ingrid and wheat is reflected by an intermediate number of HR cells. Cells neighboring HR cells showed NBT staining with a frequency of $66 \%$ (Fig. 3) 24 hai.

The wheat cv. Kanzler attacked by B. graminis f. sp. hordei exhibited at 18 hai the highest frequency of combined cell wall penetration and NBT staining in $49 \%$ of all interactions $(68 \%$ of PLC) (Fig. 3). An additional $24 \%$ of all interactions exhibited NBT staining in the epidermis or mesophyll neighbor cells, more than half of which had mounted an HR. At 24 hai, HR was determined in $84 \%$ of attacked cells, $93 \%$ of which had neighbor cells with NBT staining.

\section{Frequencies of simultaneous $\mathrm{O}_{2}{ }^{--}$and $\mathrm{H}_{2} \mathrm{O}_{2}$ staining.}

We quantified DAB-NBT double staining patterns in a set of independent experiments. Quantification of staining phenotypes clearly showed that whole-cell DAB staining was intimately related to HR in barley and wheat. Ingrid and Manchuria showed whole-cell DAB staining in 90 and $76 \%$ of HR cells, respectively, while Kanzler displayed the highest frequency with $92 \%$ (Fig. 4). Papillae in NPLC were mostly free of formazan but DAB positive. However, Manchuria displayed $55 \%$ of NPLC without any staining. PLC principally displayed

\section{A NBT Staining at 18 hai $\quad$ attacked cell $\quad$ nneighbor cell stain}
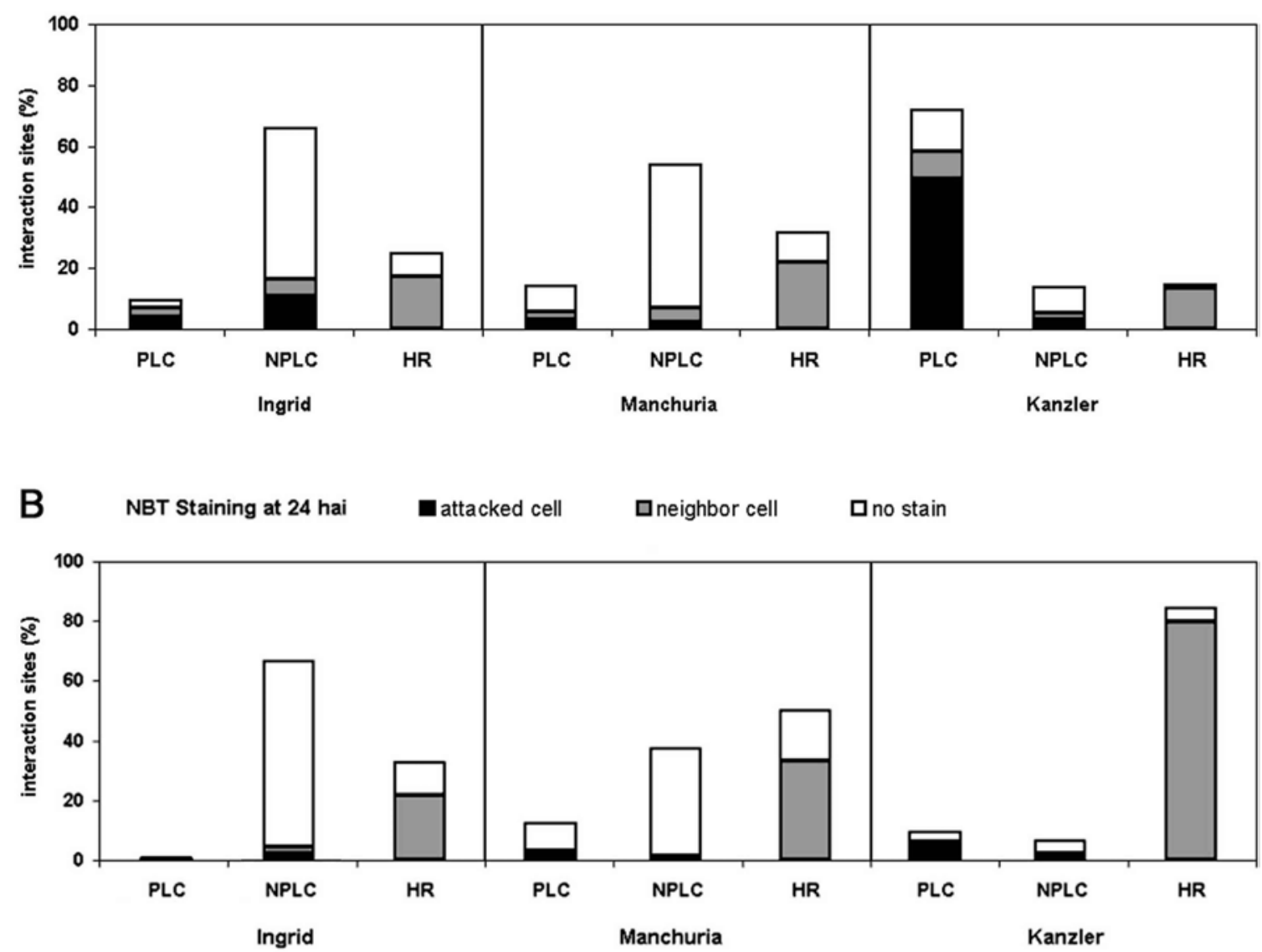

Fig. 3. Quantitative cytological analysis of $\mathrm{O}_{2}{ }^{--}$generation in the nonhost barley cvs. Ingrid and Manchuria upon infection with the Blumeria graminis f. sp. tritici, and the nonhost wheat $\mathrm{cv}$. Kanzler with B. graminis f. sp. hordei. Primary leaves were inoculated and injected with a solution of nitroblue tetrazolium (NBT) and azide at A, 18 and B, 24 hours after inoculation. Single-cell interaction-types were categorized into: nonpenetrated living cells (NPLC), which formed effective papillae and in which no haustorium initial was detected; penetrated living cells (PLC), in which a haustorium initial is detected; and hypersensitive reaction (HR), in which the attacked cell underwent cell death. Principally, three NBT staining patterns were differentiated: NBT staining in the attacked cell; accumulation of staining in the adjacent neighbor cell of an attacked cell; and cells which displayed no staining. Addition of the columns comprises $100 \%$ of all interaction sites for each cultivar-pathogen combination. Each column represents an average value of four repetitions of at least 100 single-cell interaction sites per leaf. Repetition of the experiment led to results very similar to those shown. 
NBT staining (e.g., Kanzler), in which $45 \%$ of attacked cells were penetrated and $71 \%$ of them showed NBT staining (Fig. 4). Importantly, whole-cell DAB staining in HR cells clearly was associated with simultaneous NBT staining in epidermal or mesophyll neighbor cells. In Kanzler, $71 \%$ of HR sites displayed this pattern of double staining.

\section{DISCUSSION}

The data presented here provide evidence for distinct roles of superoxide and hydrogen peroxide in the nonhost interaction of cereals and inappropriate formae speciales of $B$. graminis. Although highly localized $\mathrm{O}_{2}{ }^{--}$generation is associated directly with successful penetration and accumulates in living cells neighboring $\mathrm{HR}$ cells, $\mathrm{H}_{2} \mathrm{O}_{2}$ accumulation is linked to penetration resistance and the execution of HR cell death.

Nonhost interaction patterns of $B$. graminis with cereals were both species and genotype specific. Barley lines, especially Ingrid, displayed a higher penetration resistance compared with the wheat cv. Kanzler, which was penetrated at a high frequency and displayed an HR-related resistance mechanism. We found a close temporal and spatial association between successful penetration and $\mathrm{O}_{2}{ }^{--}$generation. This indicates that $\mathrm{O}_{2}{ }^{-}$most probably was triggered in all three interactions by penetration (i.e., by contact of the host plasma membrane with fungal structures [penetration peg]). As shown in Figure $2 \mathrm{~J} \mathrm{O}_{2}^{--}$production is triggered very early during penetration. These results are in accordance with those found in the appropriate interaction of barley with the $B$. graminis $\mathrm{f}$. $\mathrm{sp}$. hordei, in which $\mathrm{O}_{2}^{-}$generation is triggered in a race-unspecific manner (Hückelhoven et al. 2000; Hückelhoven and Kogel 1998). Similarly, NBT reduction was observed in spatial association with penetration of parsley and potato cells by Phytophthora infestans and in cowpea penetrated by cowpea rust fungus (Doke 1983; Heath 1998; Schmelzer 2002). These observations suggest that $\mathrm{O}_{2}{ }^{--}$also could have a role in cellular accessibility to $B$. graminis and other directly penetrating pathogens, because it was detected in spatiotemporal association with attempted and successful penetration. It is conceivable that low quantities of $\mathrm{O}_{2}{ }^{--}$contribute to penetration by means of cell-wall loosening by polymer breakdown (Schopfer et al. 2002). Mellersh and associates (2002) observed a transient NBT reduction under newly formed appressoria prior to attempted penetration of nonhost cowpea by the plantain powdery mildew fungus, Erysiphe cichoracearum.

Manchuria is highly susceptible to appropriate formae speciales displaying extremely low levels of penetration resistance (unpublished results). Manchuria also was quite accessible for inappropriate $B$. graminis; therefore, it seems to display a generally less effective defense response. This is underscored by a low ROI production capacity at early interaction stages. The relatively low amount of DAB-staining at sites of penetration attempts (Fig. 4B) argues for a link between a low $\mathrm{H}_{2} \mathrm{O}_{2}$ accumulation capacity and high accessibility to $B$. graminis f. sp. tritici. Nevertheless, Manchuria is able to stop $99 \%$ of penetrating B. graminis f. sp. tritici germlings by a delayed HR at 3 to 7 days after inoculation (data not shown). Higher penetration rates in Manchuria were concomitant to an increased HR frequency when compared with Ingrid, supporting a general connection between penetration and cell death in nonhost interactions (Collins et al. 2003; Peterhänsel et al. 1997). Together, cultivar-specific differences in the nonhost response of barley to $B$. graminis f. sp. tritici indicate a possible contribution of avirulence and resistance gene-like compounds to formae speciales nonhost resistance. The influence of avirulence factors in nonhost
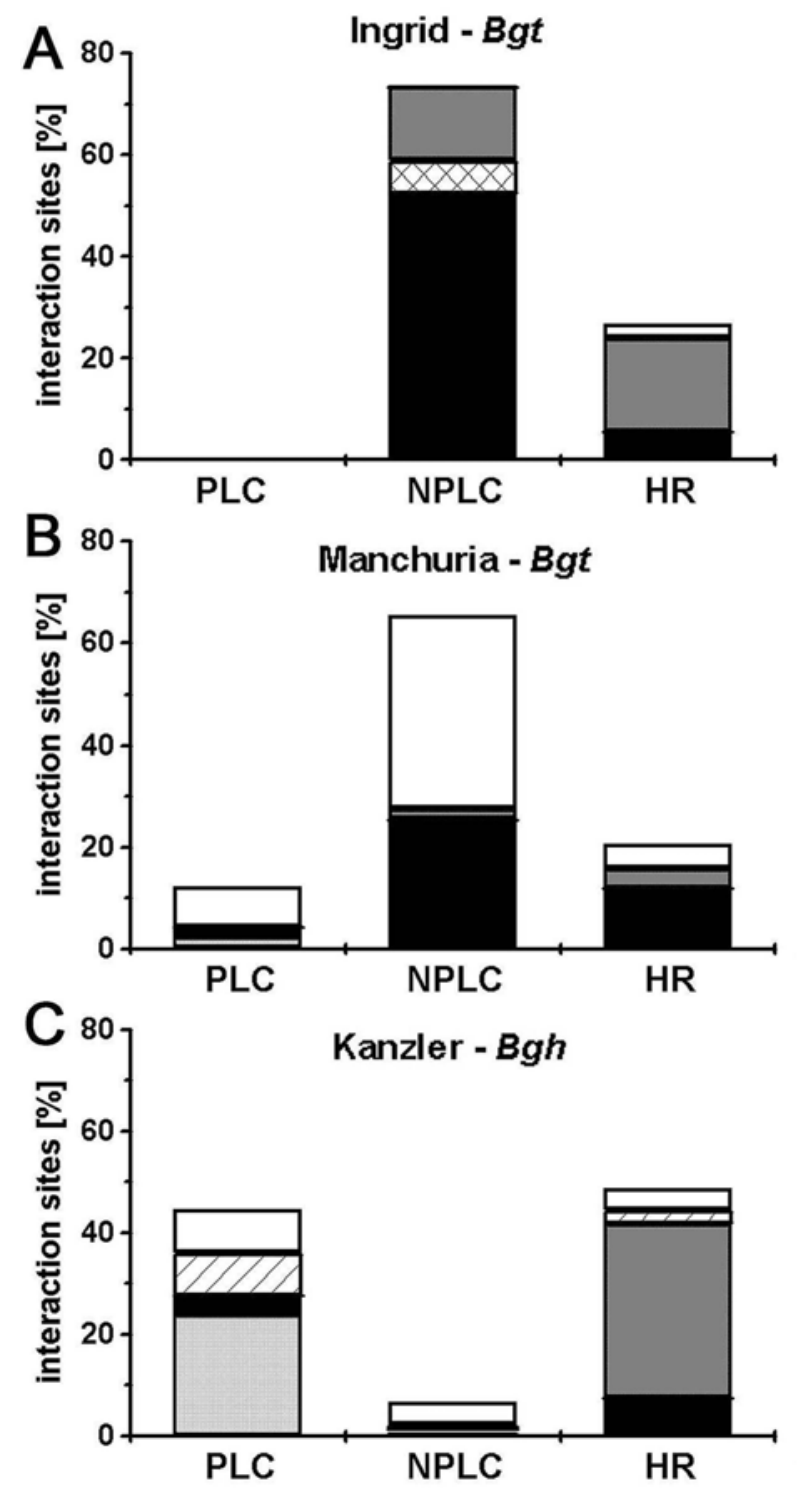

Fig. 4. Quantitative cytological analysis of $\mathrm{O}_{2}{ }^{--}$and $\mathrm{H}_{2} \mathrm{O}_{2}$ generation in the nonhost barley cvs. A, Ingrid and $\mathbf{B}$, Manchuria upon infection with Blumeria graminis f. sp. tritici (Bgt) and $\mathbf{C}$, the nonhost wheat cv. Kanzler with $B$. graminis f. sp. hordei $(B g h)$. Primary leaves were inoculated, stained with DAB 18 hours after inoculation by uptake into excised leaves, and subsequently injected with a solution of nitroblue tetrazolium (NBT) and azide. Single-cell interaction-types were categorized into penetrated living cells (PLC), nonpenetrated living cells (NPLC), and hypersensitive response (HR). Staining patterns in the interaction types were subdivided into attacked cells with no staining (no stain), NBT staining only in neighbor cells (neighbor cell-NBT), attacked cells which presented 3,3-diaminobenzidine (DAB) staining and were accompanied by NBT staining in adjacent neighbor cells (attacked cell-DAB/neighbor cell-NBT), attacked cells in which NBT as well as DAB was detectable (attacked cell-NBT-DAB), attacked cells with DAB staining (attacked cell-DAB), and attacked cells with NBT accumulation (attacked cellNBT). Addition of the columns comprises $100 \%$ of all interaction sites for each cultivar-pathogen combination. Importantly, attacked cells displayed subcellular DAB staining in papillae in NPLC but whole-cell DAB staining in HR. Papillae were DAB stained, whereas NBT staining rarely occurred near it or dispersed in the cell. Each column represents an average value of four repetitions of at least 100 single-cell interaction sites per leaf. 
interactions is further supported by Tosa and colleagues (1990), who observed differences in the defense reactions of nonhost barley and wheat lines to different $B$. graminis isolates.

Generation of ROI has been related to cell death in many plant-pathogen interactions. Although $\mathrm{O}_{2}{ }^{-}$accumulation is linked to the HR of barley and wheat cells attacked by inappropriate formae speciales of $B$. graminis, we exclusively localized $\mathrm{O}_{2}{ }^{-}$in living cells, most frequently after penetration. Penetrated cells of all genotypes finally mounted an HR. This indicates that $\mathrm{O}_{2}{ }^{--}$precedes $\mathrm{HR}$ but is not necessarily responsible for triggering it. This is substantiated by the earlier observation of a $\mathrm{O}_{2}^{\cdot-}$ accumulation in $B$. graminis $\mathrm{f}$. sp. hordei-penetrated barley cells of both the susceptible and Mla12-resistant near-isogenic line of cv. Pallas (Hückelhoven and Kogel 1998). However, in the genetic background of Pallas, $\mathrm{O}_{2}{ }^{--}$generation was somewhat stronger in Mla12resistant barley when compared with its susceptible parent line (Hückelhoven and Kogel 1998), indicating a possible feedback of race-specific recognition on nonspecific $\mathrm{O}_{2}{ }^{-}$ production. Hence, it appears possible that $R$ gene-like factors of wheat contribute to nonhost resistance to $B$. graminis f. sp. hordei and might have been responsible for the extremely high rate of $\mathrm{O}_{2}{ }^{--}$generation in wheat. We found cytological evidence suggesting the involvement of a diffusible molecule capable of triggering $\mathrm{O}_{2}{ }^{--}$generation. $\mathrm{O}_{2}{ }^{-}$was detected in cells separated from the attacked cell by one or more epidermal cells. The cells displayed $\mathrm{O}_{2}{ }^{--}$generation at the plasma membrane in anticlinal walls facing the attacked cell. Perception of elicitors has been involved in the activation of the NADPH oxidase (Allan and Fluhr 1997; Yoshioka et al. 2003). Interestingly, $\mathrm{O}_{2}{ }^{-}$also was present consistently in cells neighboring $\mathrm{HR}$ cells. Neighbor cells with $\mathrm{O}_{2}{ }^{-}$accumulation did not undergo cell death at later time points ( 72 hai; data not shown). This again underlines the point that $\mathrm{O}_{2}{ }^{-}$alone is not a single key determinant for the activation of cell death.

A dual role has been assigned to $\mathrm{O}_{2}{ }^{-}$. On the one hand, to $\mathrm{O}_{2}{ }^{-}$has been ascribed the capacity to induce genes encoding cellular protectants (e.g., glutathione-S-transferase and glutathione peroxidase) (Levine et al. 1994) and leads, in animal cells, to mitogenicity (Suh et al. 1999). On the other hand, $\mathrm{O}_{2}{ }^{-}$ is capable of causing cell damage directly or indirectly by participating in the so-called Fenton reaction, generating the highly reactive hydroxyl radical (Benov 2001; HammondKosack and Jones 1996). In both scenarios, $\mathrm{O}_{2}{ }^{-}$might act as a general stress signal leading to cell conditioning. This may play a role in cell survival but, simultaneously, may provoke a reduction in the cell death threshold when an additional signal is perceived. The phenomenon of locally induced inaccessibility and potentiation of hypersensitive resistance to virulent $B$. graminis in the neighborhood of HR cells, which prevented infection by inappropriate or avirulent $B$. graminis, is well established (Lyngkjær and Carver 2000). It is tempting to speculate that $\mathrm{O}_{2}^{--}$could have a role in this type of locally induced resistance and conditioning for HR.

Simultaneous NBT-DAB double staining revealed distinct spatial generation of $\mathrm{H}_{2} \mathrm{O}_{2}$ and $\mathrm{O}_{2}{ }^{-}$at 18 hai. Because $\mathrm{O}_{2}{ }^{-}$ spontaneously dismutates to $\mathrm{H}_{2} \mathrm{O}_{2}$ and $\mathrm{O}_{2}$, it is conspicuous that we rarely found clear DAB staining at sites of NBT staining. This might be explained by the fact that DAB staining is limited by the availability of $\mathrm{H}_{2} \mathrm{O}_{2}$ but, in addition, depends on peroxidases (Thordal-Christensen et al. 1997). These enzymes are inhibited by azide in the NBT solution. However, for double staining, NBT was applied after DAB staining. Together, though detection thresholds for $\mathrm{O}_{2}{ }^{--}$and $\mathrm{H}_{2} \mathrm{O}_{2}$ might be different, simultaneous separated localization and timing of $\mathrm{H}_{2} \mathrm{O}_{2}$ and $\mathrm{O}_{2}{ }^{-}$- detection suggests at least partially different sources of ROI. Similar observations were made in our earlier studies in the barley-B. graminis f. sp. hordei interaction (Hückelhoven and Kogel 2003) and in the nonhost cowpea-E. cichoracearum interaction by Mellersh and associates (2002).

$\mathrm{O}_{2}{ }^{--}$was located predominantly near the plasma membrane under the appressorial germ tube at early time points, suggesting an involvement of a membrane-located NADPH oxidase. Plant sequence homologues of the gp91 ${ }^{\text {PHOX }}$, the catalytic subunit of the NADPH oxidase, have been isolated from several plants, including barley (Amicucci et al. 1999; Groom et al. 1996; Hückelhoven et al. 2001b; Keller et al. 1998; Torres et al. 1998; Yoshioka et al. 2003; unpublished results). $\mathrm{O}_{2}{ }^{--}$also was detected intracellularly in vesicle-like bodies. NADPH oxidase could be transported in Golgi vesicles to the plasma membrane in an activated state. Another interpretation is that peroxisomal $\mathrm{O}_{2}{ }^{--}$sources might contribute to intracellular $\mathrm{O}_{2}{ }^{--}$generation (Corpas et al. 2001). Separately, $\mathrm{H}_{2} \mathrm{O}_{2}$ accumulated in papillae and vesicle-like bodies larger than those stained by NBT or in the whole cell during HR. Several sources have been proposed for $\mathrm{H}_{2} \mathrm{O}_{2}$ production; NADPH oxidases, cell wall peroxidases, amine oxidases, and oxalate oxidases may well contribute in a spatiotemporal-specific manner (Allan and Fluhr 1997; Bolwell and Wojtaszek 1997; Sagi and Fluhr 2001; Zhou et al. 1998). Evidence supporting a differential ROI generation where different stimuli induced ROI generation have been described (Allan and Fluhr 1997; Bolwell et al. 1998). Alternatively, different subcellular antioxidant activities might contribute to local redox changes visualized by distinct NBT and DAB staining patterns.

Mellersh and associates (2002) reported recently that $\mathrm{H}_{2} \mathrm{O}_{2}$ scavenging increased fungal penetration success on different nonhosts, whereas $\mathrm{O}_{2}^{--}$removal by superoxide dismutase was inefficient. This indicates a crucial role of $\mathrm{H}_{2} \mathrm{O}_{2}$ but not of $\mathrm{O}_{2}{ }^{--}$in penetration resistance to inappropriate fungi. Accordingly, catalase infiltration into nonhost barley led to a partially reduced penetration resistance to $B$. graminis f. $\mathrm{sp}$. tritici (unpublished observations). Although the experiments were performed several times, observed effects were relatively weak when compared with those found by Mellersh and associates (2002) in the cowpea-E. cichoracearum interaction. Nevertheless, we observed additional effects of catalase on nonhost HR of barley. Catalase seemed to support $\mathrm{HR}$ when applied before inoculation, probably by scavenging $\mathrm{H}_{2} \mathrm{O}_{2}$ and interfering with papillae formation, thereby provoking more penetration. On the other hand, it inhibited HR when applied at 12 to 14 hai, interfering directly with wholecell $\mathrm{H}_{2} \mathrm{O}_{2}$ accumulation during $\mathrm{HR}$. These observations underline a pivotal role of $\mathrm{H}_{2} \mathrm{O}_{2}$. In contrast, $\mathrm{O}_{2}{ }^{-}$remains a more enigmatic component of plant-pathogen resistance. Our data demonstrate that a thorough evaluation of ROI function in host-parasite interaction implicitly requires consideration of the complex spatiotemporal differences in the accumulation of individual ROI.

\section{MATERIALS AND METHODS}

Plants, pathogens, and inoculation.

Barley lines Ingrid and Manchuria and wheat line Kanzler were grown in a growth chamber at $18^{\circ} \mathrm{C}$ with $60 \%$ humidity and a photoperiod of $16 \mathrm{~h}\left(60 \mu \mathrm{mol} \mathrm{m} \mathrm{m}^{-2} \mathrm{~s}^{-2}\right.$ photon flux density). Inoculation was performed by air current dispersion in an inoculation tower. Primary leaves were inoculated with 10 to 20 conidia $/ \mathrm{mm}^{2} 7$ days after germination using B. graminis f. sp. tritici isolate A95 for barley and B. graminis f. sp. hordei isolate A6 for wheat. Fungi were produced under the same conditions. B. graminis f. sp. Tritici A95 was grown on wheat line Kanzler and B. graminis f. sp. Hordei A6 on barley line Golden Promise. 
Microscopic analysis and staining.

Solution for in situ detection of $\mathrm{O}_{2}{ }^{-}$contained NBT at $1 \mathrm{mg}$ $\mathrm{ml}^{-1}$ in $10 \mathrm{~nm} \mathrm{NaN}$ and $10 \mathrm{mM}$ potassium phosphate buffer, $\mathrm{pH}$ 7.8. For time-course studies of $\mathrm{O}_{2}{ }^{-}$generation, $1 \mathrm{ml}$ of the solution was injected (Hagborg 1970) into primary leaves as described by Hückelhoven and Kogel (1998), allowed to act for $25 \mathrm{~min}$, and harvested at 15, 18, 21, and 24 hai.

Simultaneous in situ detection of $\mathrm{H}_{2} \mathrm{O}_{2}$ and $\mathrm{O}_{2}{ }^{-}$was achieved by an uptake method as described previously (Hückelhoven et al. 1999; Thordal-Christensen et al. 1997) of diaminobenzidine at $1 \mathrm{mg} \mathrm{ml}^{-1}$, followed by injection of NBT solution as described after $3 \mathrm{~h}$, which was allowed to act for 25 min and harvested at 18 hai.

After harvest at indicated time points, leaf samples were bleached and, subsequently, fungal structures were stained (Hückelhoven and Kogel 1998). Only epidermal cells type A and B were utilized for evaluation (Koga et al. 1990).

HR was identified by whole-cell autofluorescence and loss of cytoplasmic strands and cytoplasm granulation. Penetration was established by the detection of a haustorium initial. We performed bright-field and fluorescence microscopy as described by Hückelhoven and Kogel (1998).

\section{ACKNOWLEDGMENTS}

This work was supported by the Deutsche Akademischer Austauschdienst and the BASF AG.

\section{LITERATURE CITED}

Ádám, A., Farkas, T., Somlyai, G., Hevesi, M., and Király, Z. 1989. Consequence of $\mathrm{O}_{2}{ }^{--}$generation during bacterially induced hypersensitive reaction in tobacco: deterioration of membrane lipids. Physiol. Mol. Plant Pathol. 34:13-26.

Allan, A. C., and Fluhr, R. 1997. Two distinct sources of elicited reactive oxygen species in tobacco epidermal cells. Plant Cell 9:1559-1572.

Alvarez, M. E., Pennell, R. I., Meijer, P. J., Ishikawa, A., Dixon, R. A., and Lamb, C. 1998. Reactive oxygen intermediates mediate a systemic signal network in the establishment of plant immunity. Cell 92:773-784.

Amicucci, E., Gaschler, K., and Ward, J. M. 1999. NADPH oxidase genes from tomato (Lycopersicon escuentum) and curly leaf pondweed (Potamogeton crispus). Plant Biol. 1:524-528.

Benov, L. 2001. How superoxide radical damages the cell. Protoplasma 217:33-36.

Bolwell, G. P., Davies, D. R., Gerrish, C., Auh, C. K., and Murphy, T. M. 1998. Comparative biochemistry of the oxidative burst produced by rose and French bean cells reveals two distinct mechanisms. Plant Physiol. 116:1379-1385.

Bolwell, G. P., and Wojtaszek, P. 1997. Mechanisms for the generation of reactive oxygen species in plant defence-a broad perspective. Physiol. Mol. Plant Pathol. 51:347-366.

Bradley, D. J., Kjellbom, P., and Lamb, C. J. 1992. Elicitor- and woundinduced oxidative cross-linking of a proline-rich plant cell wall protein: a novel, rapid defense response. Cell 70:21-30.

Brisson, L. F., Tenhaken, R., and Lamb, C. 1994. Function of oxidative cross-linking of cell wall structural proteins in plant disease resistance. Plant Cell 6:1703-1712.

Collins, N. C., Thordal-Christensen, H., Lipka, V., Bau, S., Kombrink, E., Qiu, J.-L., Hückelhoven, R., Stein, M., Freialdenhoven, A., Somerville, S. C., and Schulze-Lefert, P. 2003. SNARE-protein-mediated disease resistance at the plant cell wall. Nature 425:973-977.

Carver, T. L. W., Zeyen, R. J., Robbins, M. P., and Dearne, G. A. 1992. Effects of PAL inhibitor, AOPP, on oat; barley and wheat cell responses to appropriate and inappropriate formae speciales of Erisiphe graminis DC. Physiol. Mol. Plant Pathol. 41:397-409.

Corpas, F. J., Barroso, J. B., and del Rio, L. A. 2001. Peroxisomes as a source of reactive oxygen species and nitric oxide signal molecules in plant cells. Trends Plant Sci. 6:145-150.

Delledonne, M., Zeier, J., Marocco, A., and Lamb, C. 2001. Signal interactions between nitric oxide and reactive oxygen intermediates in the plant hypersensitive disease resistance response. PNAS 98:1345413459.

Doke, N. 1983. Involvement of superoxide anion generation in the hypersensitive response of potato tuber tissues to infection with an incom- patible race of Phytophthora infestans and to the hyphal wall components. Physiol. Plant Pathol. 23:345-357.

Falk, A., Feys, B. J., Frost, L. N., Jones, J. D., Daniels, M. J., and Parker, J. E. 1999. EDS1, an essential component of R gene-mediated disease resistance in Arabidopsis has homology to eukaryotic lipases. Proc. Natl. Acad. Sci. U.S.A. 96:3292-3297.

Flor, H. H. 1971. Current status of the gene-for-gene concept. Annu. Rev. Phytopathol. 9:275-296.

Groom, Q. J., Torres, M. A., Fordham-Skelton, A. P., Hammond-Kosack, K. E., Robinson, N. J., and Jones, J. D. 1996. rbohA, a rice homologue of the mammalian gp91phox respiratory burst oxidase gene. Plant $\mathrm{J}$. 10:515-522.

Hagborg, W. A. F. 1970. A devise for injecting solutions and suspensions into thin leaves of plants. Can. J. Bot. 58:1135-1136.

Hammond-Kosack, K. E., and Jones, J. D. 1996. Resistance gene-dependent plant defense responses. Plant Cell 8:1773-1791.

Heath, M. C. 1987. Evolution of plant resistance and susceptibility to fungal invaders. Can. J. Plant Pathol. 9:389-397

Heath, M. C. 1998. Involvement of reactive oxygen species in the response of resistant (hypersensitive) or susceptible cowpeas to the cowpea rust fungus. New Phytol. 138:251-263.

Hückelhoven, R., Dechert, C., and Kogel, K.-H. 2001a. Non-host resistance of barley is associated with hydrogen peroxide burst at sites of attempted penetration by wheat powdery mildew. Mol. Plant Pathol. 2:199-205

Hückelhoven, R., Dechert, C., Trujillo, M., and Kogel, K.-H. 2001b. Differential expression of putative cell death regulator genes in nearisogenic, resistant and susceptible barley lines during interaction with the powdery mildew fungus. Plant Mol. Biol. 47:739-748.

Hückelhoven, R., Fodor, J., Trujillo, M., and Kogel, K.-H. 2000. Barley Mla and Rar mutants compromised in the hypersensitive cell death response against Blumeria graminis f. sp. hordei are modified in their ability to accumulate reactive oxygen intermediates at sites of fungal invasion. Planta 212:16-24.

Hückelhoven, R., and Kogel, K.-H. 1998. Tissue-specific superoxide generation at interaction sites in resistant and susceptible near-isogenic barley lines attacked by the powdery mildew fungus (Erysiphe graminis f. sp. hordei). Mol. Plant-Microbe Interact. 11:292-300.

Hückelhoven, R., and Kogel, K.-H. 2003. Reactive oxygen intermediates in plant-microbe interactions: Who is who in powdery mildew resistance? Planta 216:891-902.

Jabs, T., Dietrich, R. A., and Dangl, J. L. 1996. Initiation of runaway cell death in an Arabidopsis mutant by extracellular superoxide. Science 273:1853-1856.

Kamoun, S. 2001. Nonhost resistance to Phytophthora: novel prospects for a classical problem. Curr. Opin. Plant Biol. 4:295-300.

Keller, T., Damude, H. G., Werner, D., Doerner, P., Dixon, R. A., and Lamb, C. 1998. A plant homolog of the neutrophil NADPH oxidase gp91phox subunit gene encodes a plasma membrane protein with a Ca2+ binding motifs. Plant Cell 10:255-266.

Koga, H., Bushnell, W. R., and Zeyen, R. J. 1990. Specificity of cell type and timing of events associated with papilla formation and the hypersensitive reaction in leaves of Hordeum vulgare attacked by Erysiphe graminis f. sp. hordei. Can. J. Bot. 68:2344-2352.

Lamb, C., and Dixon, R. A. 1997. Oxidative burst in plant disease resistance. Annu. Rev. Plant Physiol. Plant Mol. Biol. 48:251-275.

Levine, A., Tenhaken, R., Dixon, R., and Lamb, C. 1994. $\mathrm{H}_{2} \mathrm{O}_{2}$ from the oxidative burst orchestrates the plant hypersensitive disease resistance response. Cell 79:583-593.

Lyngkjær, M. F., and Carver, T. L. W. 2000. Conditioning of cellular defence responses to powdery mildew in cereal leaves by prior attack. Mol. Plant Pathol. 1:41-49.

Matsumara, K., and Tosa, Y. 1995. The rye mildew fungus carries avirulence genes corresponding to wheat genes for resistance to races of the wheat mildew fungus. Phytopathology 85:753-756.

Mauch, F., and Dudler, R. 1993. Differential induction of distinct glutatione-S-transferases of wheat to xenobiotics and by pathogen attack. Plant Physiol. 102:1193-1201.

Mellersh, D. G., Foulds, I. V., Higgins, V. J., and Heath, M. C. 2002. $\mathrm{H}_{2} \mathrm{O}_{2}$ plays different roles in determining penetration failure in three diverse plant-fungal interactions. Plant J. 29:257-268.

Olesen, K. L., Carver, T. L. W., and Lyngkjær, M. F. 2003. Fungal suppression of resistance against inappropriate Blumeria graminis formae speciales in barley, oat and wheat. Physiol. Mol. Plant Pathol. 62:37-50

Peterhänsel, C., Freialdenhoven, A., Kurth, J., Kolsch, R., and SchulzeLefert P. 1997. Interaction analyses of genes required for resistance responses to powdery mildew in barley reveal distinct pathways leading to leaf cell death. Plant Cell 9:1397-1409.

Sagi, M., and Fluhr, R. 2001. Superoxide production by plant homologues of the gp91(phox) NADPH oxidase. Modulation of activity by 
calcium and by tobacco mosaic virus infection. Plant Physiol. 126:1281-1290.

Schmelzer, E. 2002. Cell polarization, a crucial process in fungal defense. Trends Plant Sci. 7:411-415.

Schopfer, P., Liszkay, A., Bechtold, M., Frahry, G., and Wagner, A. 2002. Evidence that hydroxyl radicals mediate auxin-induced extension growth. Planta 214:821-8.

Suh, Y. A., Arnold, R. S., Lassengue, B., Shi, J., Xu, X., Sorescu, D., Chung, A. B., Griendling, K. K., and Lambeth, J. D. 1999. Cell transformation by the superoxide-generating oxidase Mox1. Nature 401:79-82.

Thordal-Christensen, H. 2003. Fresh insights into processes of nonhost resistance. Curr. Opin. Plant Biol. 6:351-357.

Thordal-Christensen, H., Zhang, Z., Wei, Y., and Collinge, D. B. 1997. Subcellular localization of $\mathrm{H}_{2} \mathrm{O}_{2}$ in plants. $\mathrm{H}_{2} \mathrm{O}_{2}$ accumulation in papillae and hypersensitive response during the barley-powdery mildew interaction. Plant J. 11:1187-1194.

Torres, M. A., Onouchi, H., Hamada, S., Machida, C., Hammond-Kosack, K. E., and Jones, J. D. 1998. Six Arabidopsis thaliana homologues of the human respiratory burst oxidase (gp91 ${ }^{\text {phox }}$ ). Plant J. 14:365-370.

Tosa, Y., and Tada, S. 1990. Operation of resistance genes in wheat to Erysiphe graminis f. sp. tritici against $E$. graminis f. sp. agropyri. Genome 33:231-234
Tosa, Y., and Sakai, K. 1990. The genetics of resistance of hexaploid wheat to the wheatgrass powdery mildew fungus. Genome 33:225-230.

Tosa, Y., and Shishiyama, J. 1984. Defense reactions of barley cultivars to an inappropriate forma specialis of the powdery mildew fungus of gramineous plants. Can. J. Bot. 62:2114-2117.

Vanacker, H., Carver, T. L. W., and Foyer, C. H. 2000. Early $\mathrm{H}_{2} \mathrm{O}_{2}$ accumulation in mesophyll cells leads to induction of glutathione during the hyper-sensitive response in the barley-powdery mildew interaction. Plant Physiol. 123:1289-1300.

Yoshioka, H., Numata, N., Nakajima, K., Katou, S., Kawakita, K., Rowland O., Jones, J. D., and Doke, N. 2003. Nicotiana benthamiana gp91 ${ }^{\text {phox }}$ homologs NbrbohA and NbrbohB participate in $\mathrm{H}_{2} \mathrm{O}_{2}$ accumulation and resistance to Phytophthora infestans. Plant Cell 15:706-718.

Yun, B. W., Atkinson, H. A., Gaborit, C., Greenland, A., Read, N. D., Pallas, J. A., and Loake, G. J. 2003. Loss of actin cytoskeletal function and EDS1 activity, in combination, severely compromises non-host resistance in Arabidopsis against wheat powdery mildew. Plant J. 34:768-777.

Zhou, F., Zhang, Z., Gregersen, P. L., Mikkelsen, J. D., Neergaard, E., Collinge, D. B., and Thordal-Christensen, H. 1998. Molecular characterization of the oxalate oxidase involved in the response of barley to the powdery mildew fungus. Plant Physiol. 117:33-41. 